\title{
Anesthesia human resource models: reality or pipe dreams?
}

\author{
Neil Donen MD FRCPC
}

"For every complex problem there is an easy answer .... and it's wrong." H.L. Mencken.

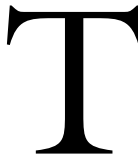

HE articles by Byrick, Craig and Carli appearing in this issue continue the tradition of the Association of Canadian Universities Departments of Anesthesia (ACUDA) actively participating in anesthesia physician resource planning (PRP) in Canada. ${ }^{1,2}$ The two articles are based on a summary of a PRP Needs Assessment and planning model developed by Eva Ryten on behalf of ACUDA. ${ }^{3}$ In 1961 the forerunner of this organization began collecting demographic data on trainees enrolled in anesthesia residency programs. Arising from this work the Canadian Anaesthetists' Society (CAS), in 1967, established an anesthesia PRP committee to extend this information to practicing clinicians. ${ }^{4}$ Although the motives for involvement may have differed, together the two organizations have been key in allowing Canadian Anesthesia PRP to stay in the forefront of documenting and assessing our specialty's physician needs.

The concern of current and future anesthesia physician shortages is not new. Since 1961, when an editorial in the Canadian Anaesthesiologists' Society Journal noted that unless solutions where found "we will find ourselves unable to provide the anaesthetists which will be required" a number of subsequent editorials have continued to echo the same refrain. ${ }^{5-8}$ The concern of physician shortages extends to most other branches in medicine. This has resulted in numerous national and provincial task forces and studies. ${ }^{\mathrm{A}} \mathrm{B}$

For many years Population-Physician (P:P) ratios were used as the standard marker for adequacy of current and future physician needs. As our understanding of the complexity of the problem relating to the issues of PRP improved, newer models have been developed. The Figure provides a simplified overview of the various factors that play a role in the planning of physician

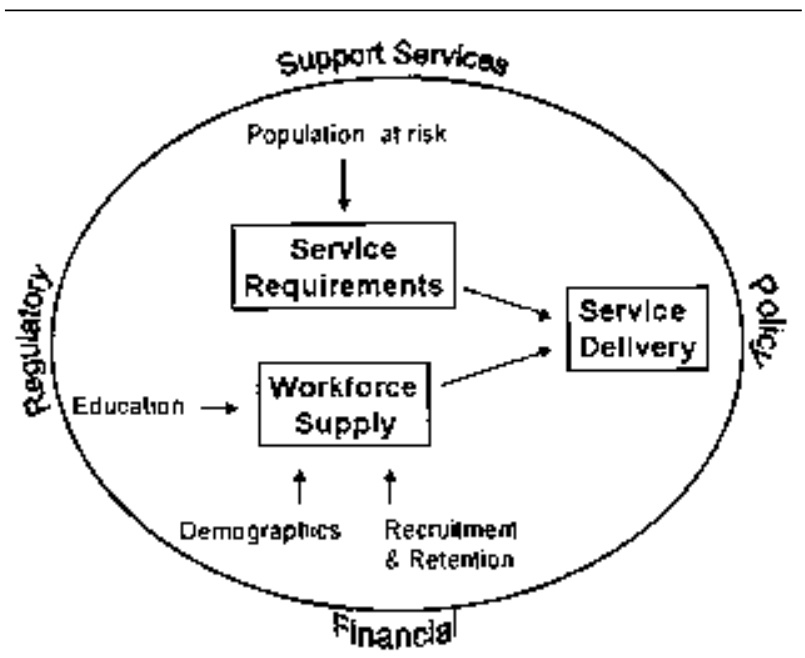

FIGURE Factors relevant to physician resource planning.

human resources. These models usually relate to the fact that ultimate deliveries of services are dependent upon demand (the service requirements) and supply (the workforce available). Both of these latter issues are themselves dependent on many factors. Service requirements relate to the population at risk and include such concerns as trends in disease, population growth and aging and the indications, real or perceived, for the service. Workforce supply is dependent

A Fooks C, Duvalko K, Schiff J. Health human resource planning in Canada: a health policy pendulum. Background paper for the National Round Table on Health Human Resources. April 2002.

Kazanjian A, MacDonald A, Rabim-Jamal S. Critical review of Canadian workforce policy models: draft preconference paper for discussant, $6^{\text {th }}$ Invitational International Physician Workforce Conference. April 2002.

From the Department of Continuing Medical Education and Professional Development, Vancouver Island Health Authority, Royal Jubilee Hospital, Victoria, British Columbia, Canada.

Address correspondence to: Dr. Neil Donen, Department of Continuing Medical Education and Professional Development, Vancouver Island Health Authority, 103 Begbie Hall, Royal Jubilee Hospital, 1900 Fort Street, Victoria, British Columbia V8R 1J8, Canada. Phone: 250-370-8425; Fax: 250-370-8556; E-mail: ndonen@shaw.ca 
on the demographics of the anesthesia work force (age, gender, geographical distribution, migration, scope of practice and lifestyle), education of the physicians delivering the services (numbers and mix of training positions, cost of education, content of the training) as well as the ability to attract physicians into the practice of anesthesia and then retain them in the town, city, province or country.

Generally not considered in many of these planning models are four other critical factors. For lack of a better expression I call them the forgotten factors. These include the all important support services, specifically nursing and/or respiratory technicians, that are essential and integral to the anesthesiologist being able to provide and deliver the necessary services. Changing regulatory and credentialing requirements from various authorities are a second important factor that unexpectedly may influence the meeting of service requirements. A third factor one has to be aware of are the effects of funding and other fiscal issues on both the supply and demand of services. Finally, changes in government policies can have dramatic effects. Witness, as examples, decisions by provincial governments to "re-engineer health care" or to selectively implement medical school enrolment recommendations from the Barer-Stoddard report.

Physician resource planning assessment and forecasting models currently fall into one of four categories or combinations thereof. ${ }^{A}$ (i) Supply-based forecasting uses historical or current numbers of physicians in a particular region and projects future need based on population growth in that region (P:P ratios). (ii) Utilization or Demand forecasting also uses P:P ratios but includes patterns and actual utilization of services together with workforce supply needs in its projections. (iii) Needs-based Planning uses a different approach. Planning is based on measures of disease prevalence as well as age and gender distribution of the population in the region. Physician need is then estimated. (iv) Benchmarking assesses an index region that is deemed to have excellent care based on its population health index. Forecasting builds on this benchmark to project future physician requirements.

In the past ten years at least 28 Canadian workforce policy models have been developed. In addition each Province and Territory has established some form of a physician workforce-planning model. ${ }^{\mathrm{B}}$ As part of their preparation of the 2002 background paper to the National Round Table on Health Human Resources, Fooks and her colleagues interviewed many of these various chairs of physician resource commissions, task forces etc. ${ }^{\mathrm{A}}$ They identified a number of key factors that either impeded or assisted the implementation of
PRP programs. Execution on many occasions failed because of the failure of the implementers to understand the multidimensional nature and complexity of PRP. This led to selective rather than comprehensive program implementation. Political cycles and financial issues were identified as other impediments as governments tended to put into place programs that were cheap, highly visible and provided short term solutions. The lack of a central coordinating structure and involvement of a broad base of players with different accountabilities and self-interest were other impediments noted. Finally, on a practical note, it is important to realize that many of the models do have implications with respect to jobs and income.

The interviewees also identified criteria that were successful in permitting programs to be successfully developed. Central to all of them was the need for government to be actively involved and on side with the processes. This included active sponsorship by a senior government official, the presence of an internal champion and a clear understanding of the processes that government will use to respond the identified issues. Finally there was the ability to anticipate and deal with negative reactions to the proposed plan at the beginning rather than during the implementation of the plan. In a separate comment Fooks et al noted that the real issue around PRP was the need to clearly identify the objectives of any of the plans and the necessity to develop an appropriate measure of adequacy of delivery of services.

Given the obvious complexity of developing an appropriate PRP model it is now useful to return to the two articles in this journal. On the surface they seem to fall far short of any successful planning model. However, one needs to remember that the articles are a summary of a report. The key is, in fact, to look at all three as a whole and not individually in isolation. In her report Ryten clearly identifies that the model is but one part of the solution. ${ }^{3}$ She notes the need to actually decide whether the current supply of anesthesiologists is adequate i.e., developing markers of need for, and volumes of, services. She also stresses the importance of physician demographics such as age distribution, gender, work patterns and geographic distribution. Ryten further urges ACUDA to look beyond the need of identifying purely specialist anesthesia services required. Regular reviews of the different variables affecting PRP and indicators to see if the predictions were on track were other important factors considered to be necessary for the successful use of this model. Although most recent models talk about Full Time Equivalent Physicians (FTE) she correctly points out that with any given physician demograph- 
ics this could translate into 2,000 anesthesiologists working full-time or 4,000 anesthesiologists working half time. Thus the need to undertake a head count and to take into account these demographic issues as the key variable is, and will continue to be, the number of individuals actually delivering the service. Ryten stresses the need to include the successful factors that will make implementation of any workforce plan viable and to minimize the impediments to this process. Byrick, Craig and Carli demonstrate that the model developed is feasible and workable in the anesthesia setting. Perhaps its most important significance is that it is easily reproduced. ${ }^{1,2}$ They also provide some interesting comments and background to the political issues that surround past PRP. One interesting question raised is the potential to use alternative providers to deliver some of the necessary services. This may be critical in helping us to provide effective anesthesia services to the population at large.

Having developed a model that appears workable the big question really is - Can we make it work? As we plan and move forward we have to be acutely aware of the ongoing issue of the shortfalls of nursing and anesthesia human resources south of our borders. ${ }^{9,10}$ The message from Ryten is clear. "The best model in the world will be of little practical utility if the authorities that have to take decisions don't pay attention." ACUDA has raised the bar. It is now up to them and the CAS to take up the political cause to ensure that government will become involved and really move the process forward. If they don't, the reality is that we will be left with just another model, a worsening of the anesthesia physician resource crisis and another pipe dream.

\section{Les modèles de} ressources humaines en anesthésie : une réalité ou des chimères ?

" $A$ tout problème complexe, il y a une solution simple...mais mauvaise” H.L. Mencken.

Les articles de Byrick, Craig et Carli qui paraissent dans le présent numéro poursuivent la tradition de l'Association canadienne des départements universi- taires d'anesthésie (ACDUA) en participant activement à la planification des ressources médicales (PRM) en anesthésie au Canada. ${ }^{1,2}$ Les deux articles se fondent sur un résumé de l'Évaluation des besoins de PRM et sur le modèle de planification qu'Eva Ryten a réalisé au nom de l'ACDUA. ${ }^{3}$ En 1961, le promoteur de cet organisme a commencé à recueillir des données démographiques sur les stagiaires inscrits aux programmes de résidence en anesthésie. Née de ce travail en 1967, la Société canadienne d'anesthésie (SCA) a créé une commission de PRM en anesthésie pour diffuser ces informations aux cliniciens. ${ }^{4}$ Malgré leurs différents motifs d'implication, les deux organismes ont permis à la PRM en anesthésie canadienne de demeurer au premier plan en documentant et en évaluant les besoins en ressources médicales de notre spécialité.

L'inquiétude entourant la pénurie actuelle et future d'anesthésiologistes n'est pas nouvelle. Depuis 1961, alors qu'un éditorial du Journal de la Société canadienne des anesthésistes soulignait qu'à moins de trouver des solutions, "nous allions nous retrouver dans l'impossibilité de fournir le nombre nécessaire de spécialistes", un certain nombre d'éditoriaux ont par la suite répété le même refrain. ${ }^{5-8}$ Cette pénurie de médecins s'étend à la plupart des autres spécialités médicales. De nombreuses équipes de travail et des études nationales et provinciales en ont résulté. ${ }^{\mathrm{A} B}$

Pendant de nombreuses années, les ratios Population-Médecin (P:M) ont été utilisés comme indicateurs normalisés de la justesse des besoins actuels et futurs de médecins. À mesure qu'évolue notre compréhension de la complexité du problème relié aux questions de PRM, de nouveaux modèles se développent. La Figure présente une vue d'ensemble des différents facteurs qui jouent un rôle dans la planification des ressources humaines médicales. Ces modèles font généralement ressortir que la prestation de services dépend finalement de l'offre (le personnel disponible) et de la demande (les besoins de services). Ces deux derniers éléments dépendent eux-mêmes de nombreux facteurs. Les besoins de services concernent la population à risque et comprennent l'évolution des maladies, l'accroissement de la population et le vieillissement, de même que les indications de services, réelles ou perçues. L'offre de personnel dépend de

A Fooks C, Duvalko K, Schiff J. Health human resource planning in Canada: a health policy pendulum. Background paper for the National Round Table on Health Human Resources. April 2002.

B Kazanjian A, MacDonald A, Rahim-Jamal S. Critical review of Canadian workforce policy models: draft preconference paper for discussant, 6th Invitational International Physician Workforce Conference. April 2002. 


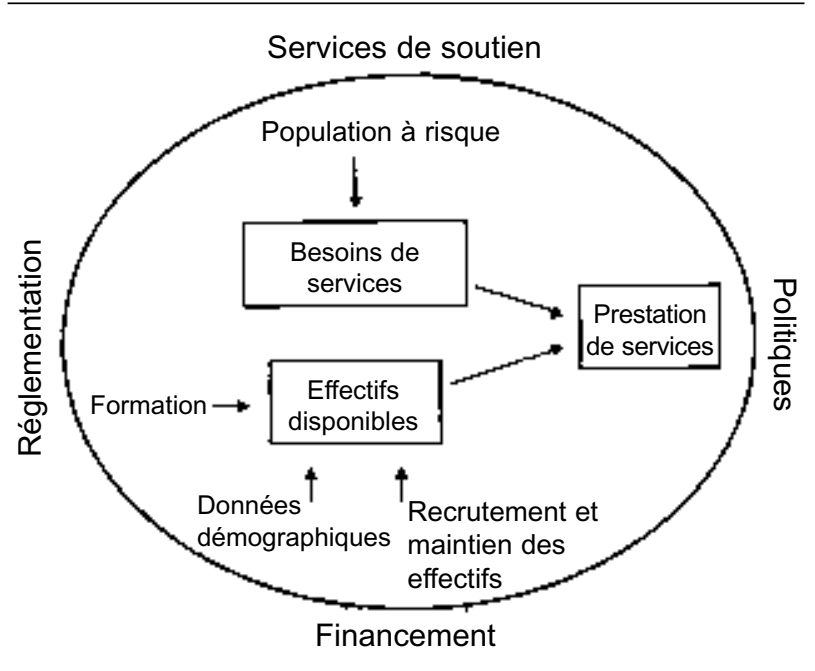

FIGURE Facteurs applicables à la planification des ressources médicales.

l'évolution des effectifs de la population active disponible (âge, sexe, distribution géographique, migration, cadre des fonctions et style de vie), la formation des médecins qui offrent les services (nombre et diversité des places de formation, coût de la formation, contenu de la formation) aussi bien que de la capacité d'attirer des médecins à la pratique de l'anesthésie et de les retenir ensuite dans la ville, la province ou le pays.

Quatre autres facteurs critiques ne sont habituellement pas pris en considération dans ces modèles de planification. Faute d'une meilleure appellation, nous les appellerons des facteurs oubliés. Ils comprennent tous les importants services de soutien, en particulier le personnel infirmier et/ou les inhalothérapeutes, qui sont essentiels et indispensables pour l'anesthésiologiste et capables de prévoir et de dispenser les services nécessaires. La modification des exigences réglementaires et d'accréditation par diverses autorités constitue un deuxième facteur important qui peut inopinément influencer la façon de répondre aux besoins de services. Un troisième facteur dont il faut être conscient sont les effets du financement et d'autres questions fiscales sur l'offre et la demande de services. Enfin, les changements de politiques gouvernementales peuvent avoir des effets considérables. Regardons, par exemple, les décisions des gouvernements provinciaux quant à la "réforme des soins de santé" ou à la mise en application sélective des recommandations d'inscription aux écoles de médecine à partir du rapport BarerStoddard.
L'évaluation de la planification des ressources médicales et des modèles prévisionnels se divise actuellement en quatre catégories ou en combinaisons de ces catégories. ${ }^{\mathrm{A}}$ (i) Les prévisions fondées sur l'offre utilisent le nombre rétrospectif ou actuel de médecins dans une région donnée et projettent les besoins futurs d'après la croissance de la population de cette région (ratio P:M). (ii) Les prévisions d'utilisation ou de la demande se servent aussi du ratio P:M, mais incluent aussi les modèles et l'utilisation réelle des services ainsi que les besoins d'effectifs. (iii) La planification fondée sur les besoins utilise une approche différente. Elle tient compte des mesures de prévalence des maladies ainsi que de l'âge et de la distribution selon le sexe de la population d'une région. Les besoins de médecins sont ensuite estimés. (iv) La référenciation évalue une région indice considérée comme ayant des soins excellents d'après l'index de santé de sa population. La prévision se construit à partir de cette référence et projette ses besoins de médecins futurs.

Au cours des dix dernières années, au moins 28 modèles politiques d'effectifs ont été élaborés. De plus, chaque Province et Territoire a créé un certain modèle de planification des effectifs médicaux. ${ }^{\mathrm{B}}$ Dans le cadre de la préparation d'un rapport sur la situation en 2002 pour la Table ronde nationale sur les ressources humaines en santé, Fooks et ses collègues se sont entretenus avec de nombreux présidents des différentes commissions sur les ressources médicales, des groupes d'études, etc.A Ils ont dégagé un nombre de facteurs clé qui contribuent ou non à l'application des programmes de PRM. L'exécution des programmes a échoué en maintes occasions parce que ceux qui en avaient la charge ne comprenaient pas la nature multidimensionnelle et la complexité de la PRM. C'est ce qui a conduit à la création sélective plutôt que généralisée du programme. Les cycles politiques et les questions financières ont été reconnus comme d'autres contraintes, car les gouvernements tendent à mettre en place des programmes économiques d'une grande visibilité et ils n'apportent que des solutions à court terme. L'absence d'une structure de coordination centrale et la participation d'une large base de joueurs dont les obligations et les intérêts personnels diffèrent sont aussi des inconvénients. Enfin, au plan pratique, il faut bien reconnaître que beaucoup de modèles ont des implications sur les emplois et le revenu.

Les répondants ont aussi nommé les critères qui avaient permis l'élaboration réussie de programmes. Le plus important était la nécessité que le gouvernement participe activement et soit en faveur du cheminement. Ce qui comporte le parrainage actif par un 
haut fonctionnaire du gouvernement, la présence d'un maitre d'œuvre interne et une compréhension claire $\mathrm{du}$ processus que le gouvernement va utiliser pour répondre aux questions soulevées. Il y a aussi la capacité d'anticiper les réactions négatives au plan proposé et d'y réagir dès le départ plutôt que pendant la mise en vigueur du plan. Dans une remarque à part, Fooks et coll. ont affirmé que l'enjeu réel autour de la PRM était la nécessité de bien déterminer les objectifs de chacun des plans et de mettre au point une mesure du caractère adéquat de la prestation des services.

Étant donné la complexité évidente de la mise au point d'un modèle de PRM, il est maintenant utile de revenir aux deux articles du présent numéro du Journal. Au premier abord, ils semblent plutôt dépourvus de tout modèle de planification effectif. Cependant, il faut se rappeler que ces articles résument un rapport. La clé est, de fait, de les considérer comme un tout et non de les regarder isolément. Dans son rapport, Ryten a clairement spécifié que le modèle n'est qu'une partie de la solution. ${ }^{3}$ Elle note qu'il faut, en réalité, décider si le nombre actuel d'anesthésiologistes est suffisant, c'est-àdire en développant des marqueurs de besoins et des volumes de services. Elle a aussi insisté sur l'importance des données démographiques sur les médecins, comme la distribution selon l'âge, le sexe, les pratiques de travail et la répartition géographique. De plus, Ryten presse l'ACDUA d'examiner la situation au-delà du seul besoin de spécifier les services spécialisés d'anesthésie. La revue régulière des différentes variables touchant la PRM et les indicateurs, qui permettent de voir si les prédictions étaient justes, sont d'autres facteurs importants à considérer dans le succès de ce modèle. Même si la plupart des modèles récents parlent de médecins en termes d'équivalent temps plein (ETP), elle a fait remarquer à juste titre que selon toute donnée démographique sur les médecins, cela pourrait se traduire par 2000 anesthésiologistes à temps complet ou 4000 à temps partiel. Ainsi, l'impératif de faire un relevé des effectifs et de tenir compte de ces questions démographiques comme étant des variables clés est, et continuera d'être, le nombre de personnes qui donnent réellement le service. Ryten a mis l'accent sur la nécessité d'inclure des facteurs qui feront en sorte que l'application de tout plan d'effectifs soit viable et de réduire les obstacles pour y parvenir. Byrick, Craig et Carli démontrent que le modèle élaboré est faisable et utilisable en anesthésie. Sa plus grande valeur significative est sans doute qu'il peut être facilement reproduit. ${ }^{1,2}$ Les auteurs ont aussi présenté certains commentaires intéressants et un portrait des questions politiques qui ont entouré la PRM dans le passé. Entre autres énoncés d'intérêt, il y a la possibilité que les services nécessaires soient rendus par d'autres personnes que les anesthésiologistes. Cette façon de voir peut faciliter la planification d'effectifs suffisants en anesthésie pour la population en général.

Maintenant que le modèle élaboré semble utilisable, la vraie question qui demeure est - Pouvons-nous le mettre en pratique ? À mesure que nous planifions et progressons, nous devons rester vivement conscients de la permanente question de la pénurie de ressources humaines en soins infirmiers et en anesthésie au sud de nos frontières. ${ }^{9} 10$ Le message de Ryten est clair. "Le meilleur modèle au monde sera de peu d'utilité si les autorités décisionnelles n'y portent pas attention." L'ACDUA a élevé la barre. Il leur appartient maintenant, avec la SCA, d'aborder la cause politique afin de s'assurer que le gouvernement participe et fasse réellement avancer le procédé. Sinon, nous nous retrouverons avec juste un modèle de plus, l'aggravation de la crise de ressources médicales en anesthésie et une autre chimère.

\section{References}

1 Byrick RJ, Craig D, Carli F. A physician workforce planning model applied to Canadian anesthesiology: assessment of needs. Can J Anesth 2002; 49: 663-70.

2 Craig D, Byrick R, Carli F. A physician workforce planning model applied to Canadian anesthesiology: planning the future supply of anesthesiologists. Can J Anesth 2002; 49: 671-77.

3 Ryten E. A physician workforce planning model for the specialty of anesthesia: Theoretical and practical considerations. http://www.anesthesia.org/acuda/en/ryten.html

4 Shephard DAE. Chapter 14: manpower in anaesthesia: the Society's perspective. In: Watching Closely Those Who Sleep: A History of the Canadian Anaesthetists' Society 1943-1993. Can J Anesth 1993: 40 (Supplement).

5 A matter for concern (Editorial). Can Anaesth Soc J 1961; 8: 89.

6 Byrick RJ, Craig DB. Consequences of inadequate Canadian physician resource planning. Can J Anesth 1999; 46: 913-8.

7 Duncan PG. Anesthesia human resources in Canada. Can J Anesth 2000; 47: 99-104.

8 Seal RF. Crisis in rural anesthesia (Editorial). Can J Rural Med 2001; 6: 241-3.

9 Bednash $G$. The decreasing supply of Registered Nurses: inevitable future or call to action? JAMA 2000; 283: 2985-7.

10 Schubert A, Eckbout G, Cooperider T, Kuhel A. Evidence of a current and lasting national anesthesia personnel shortfall: scope and implications. Mayo Clin Proc 2001; 76: 995-1010. 